\title{
Sex-specific metabolic alterations induced by environmental pollutants
}

Brigitte Le Magueresse-Battistoni, Hubert Vidal, Danielle Naville

\section{Affiliations:}

Univ-Lyon, CarMeN laboratory, INSERM U1060, INRA U1397, Université Claude Bernard Lyon1, INSA Lyon, Charles Mérieux Medical School, F-69600 Oullins, France

\section{Corresponding author:}

Dr. B. Le Magueresse-Battistoni, PhD

CarMeN laboratory, INSERM U1060, Faculté de Médecine Lyon-Sud, Chemin du Grand Revoyet, 69600 Oullins, France

Phone 33 (0)426235919, Fax 33 (0)426235916

E-mail : brigitte.lemagueresse@inserm.fr

\section{Conflicts of interest: none}

Funding: This research did not receive any specific grant from funding agencies in the public, commercial, or not-for-profit sectors. 


\begin{abstract}
Diabetes and obesity are the biggest public health challenge and the current prevalence of these chronic diseases has reached epidemic proportions worldwide. Apart from genetic alterations and lifestyle, exposure to environmental chemicals has emerged as a new cause of metabolic diseases. Notably, several compounds that mimic or oppose hormone activity defined as endocrine disruptors (EDs), may exert metabolic disturbances through interfering with the regulatory roles of the sex steroids (among other hormones) in energy homeostasis. However, most studies to date have investigated the metabolic impact of EDs on males and there is a lack of information regarding the metabolic impact of endocrine disruptors in females. There is as well a paucity of data for both sexes related to the metabolic impact resulting from the exposure to a mixture of EDs which is a more realistic scenario than the exposure to chemicals individually. Hopefully, conducting studies on both sexes in situations of multi-exposure to chemicals will help at better understanding the sex-biased mechanisms linked to endocrine disruption that could be helpful to improve and personalize treatments of diseases for which obesity is a risk factor, such as the metabolic syndrome and the hormonodependent cancers.
\end{abstract}

\title{
Bullet points:
}

Energy homeostasis is a physiological function with strong sex-dimorphic outcomes

Endocrine disruptors (EDs) are chemicals that interfere with any hormone action

EDs may induce metabolic disturbances in a sex-specific way

There is a lack of data on the metabolic impact of EDs in females

There is a lack of data on the metabolic impact of mixture of EDs in both sexes

\section{Keywords:}

Endocrine disruptors; energy homeostasis; sex-dimorphism; insulin signaling; glucose tolerance; cholesterol metabolism 


\section{Introduction}

Diabetes and obesity are the biggest public health challenge and the current prevalence of these chronic diseases has reached epidemic proportions worldwide. By 2030, it is predicted that the number of overweight people will reach 3.3 billion while diabetes will affect more than 400 million people worldwide becoming a leading cause of death [1]. Apart from genetic alterations and lifestyle, exposure to environmental chemicals has emerged as a new cause of metabolic diseases. Notably, several compounds display estrogeno-mimetic activities and models of estrogen deficiency/excess in both humans and rodents, both in males and females, have well illustrated the importance of estrogens in regulating energy homeostasis and insulin sensitivity when estrogens stay within tight physiological concentrations. Indeed, energy homeostasis is largely dependent on sex-specific mechanisms regulating eating behavior, energy expenditure, fat distribution, insulin sensitivity and glucose tolerance [2]. Accordingly, it was anticipated that compounds with estrogenic, anti-estrogenic or anti-androgenic activities will act as metabolic disruptors and that the adverse effects may be sex-specific.

In this commentary, we intend to highlight that endocrine disruptors exert metabolic disturbances through interfering with the signaling of sexual hormones, with both common and sex specific effects. A focus is made on the use of a mixture of endocrine disruptors which corresponds to a more realistic scenario than the use of individual chemicals.

\section{Historical context}

A thousand chemicals have been identified as endocrine disruptors including persistent organic molecules but also pharmaceuticals, phytoestrogens, mycotoxins [3-5]. These products which have invaded the different compartments of the environment (biota, air, water, land and aquatic sediments), accumulate and concentrate in organisms higher up the food chain (bioaccumulation). As a consequence fatty products contain a high level of persistent and lipophilic chemicals (e.g., dioxins and polychlorobiphenyls, PCBs). Food may also be contaminated by short-lived molecules such as phthalates and bisphenols migrating from food packaging and containers. Exposure to various chemicals may also occur by inhalation and dermal contact as well as by breastfeeding and by hand-to-mouth behavior in children. 
The modes of action of the endocrine disruptors are not fully characterized because they are dependent on the dose of the chemicals, the simultaneous presence of other chemicals defined as the cocktail effect (detailed later in the Commentary), the timing of exposure and the sex of the exposed individuals [6]. For example, the set of genes activated in the liver of bisphenol A (BPA)-exposed male rats depends on the dose of BPA [7]. One chemical may interact with multiple nuclear receptors (e.g., steroid receptors, xenobiotic/endobiotic receptors, the aryl hydrocarbon receptor) [6,8] and/or interfere with the signaling of different hormones such as estrogens, androgens and thyroid hormones (e.g., BPA, dioxins, phthalates and PCBs) [9]. In addition, and contrasting with the toxicology principles, the adverse effect does not obligatory occur immediately post exposure. Its occurrence is highly dependent on the timing of exposure with windows of high vulnerability coinciding with the period of differentiation of the targeted organ. For example, the fetal and perinatal periods during which food behavior, energy expenditure and differentiation of the adipose tissue are occurring constitute highly vulnerable periods, as well as puberty [3-5]. Finally, epigenetic mechanisms have been demonstrated to support adverse effects observed later in life (Developmental Origin of Human adult Diseases or DOHaD hypothesis) [10] and in non-exposed generations born from grand parents exposed during the fetal or lactation periods (transgenerational effects) $[10,11]$.

Because it has long been considered that physiological systems were similar in males and females, few experimental studies have investigated both sexes preferring males mostly because of the suspected variability due to estrous cyclicality in females. Interestingly, the discovery that chemicals were inducing developmental and reproductive disorders by interfering with any hormone action (which is the accepted definition of the endocrine disruptors, [12]) had probably opened increasing interest in studying the two sexes but also fetal and pubertal periods as well as the menopausal period. Indeed, these periods are marked by tremendous hormonal changes governing most of the physiological functions (e.g., behavior, reproduction, development, growth and energy homeostasis). As a matter of fact, first adverse effects of these chemicals were described in the field of reproduction consistent with a high number of these chemicals interfering with the signaling of estrogens and androgens. Historically, three chemicals, including the drug diethylstilbestrol (DES), the pesticide dichlorodiphenyltrichloroethane (DDT) and the antifouling paint tributyltin (TBT) have been instrumental in the understanding of the modes of actions of the endocrine disruptors $[8,13,14]$. 


\section{Energy homeostasis is a physiological function with strong sex-dimorphic traits and thus at high risk of alteration by endocrine disruptors}

Energy homeostasis comprises regulation of food behavior and efficiency, and of glycaemia at physiological levels to meet energy demands. Regulation of glycaemia involves insulin secretion by the pancreas and insulin action on liver, muscle and adipose tissues. Dysregulation as a result of pancreatic failure in insulin production or inappropriate response to insulin (i.e., insulin resistance) induces a spectrum of metabolic disturbances such as obesity, glucose intolerance, dyslipidemia, hyperinsulinaemia, low-grade inflammation leading among others to the development of diabetes or cardio-vascular diseases. An obesogen chemical will be defined as a chemical interfering with food intake and energy expenditure, energy efficiency or adipocyte hyperplasia (proliferation) and/or hypertrophy (differentiation) while a metabolic disruptor chemical (diabetogen) will interfere with insulin secretion, insulin action or both [15]. However, the distinction is not that obvious between obesogens and diabetogens as obesity is a risk factor for diabetes.

Sexual dimorphism of the process is mostly driven by the genetic sex, the programming effect of testosterone in males during the perinatal period, and the role of sex hormones at puberty [2]. For example, experimental exposure of females to testosterone during the perinatal period (which occurs in males but not in females) induces male food behavior via the androgen receptors (ARs) and leptin-resistance through activation of the estrogen receptors (ERs), both concurring to obesity in adulthood [16]. Developmental androgen excess disrupts as well energy homeostasis in adult male mice predisposing them to obesity [16]. The perinatal period is also marked by the programming of mesenchymal stem cells toward either the adipocyte or the bone lineage involving concurrent activation of ERs and peroxisome proliferator-activated receptors (PPARs) [17]. Importantly, several chemicals can activate one or several of these receptors including the mentioned historical molecules (DES, TBT and DDT) leading to obesity and/or metabolic disturbances [4,6,11].

Fat distribution is a highly sex-dimorphic trait more evidenced in adulthood. Although females have more subcutaneous adipose mass than males and males more muscle mass than women, fat subcutaneous distribution is not detrimental as compared to males which accumulate visceral fat upon body weight gain predisposing them to diabetes and cardiovascular diseases [2]. In addition, excess of estrogens such as during the estrous periods, during gestation and through pill consuming, results in insulin resistance favoring 
weight gain while estrogen deficiency such as during the menopausal transition also favors weight gain, accumulation of visceral fat and development of type 2 diabetes. Males and females also differ in the utilization of carbohydrates and lipids as fuel sources [18-20]. It indicates that while estrogens protect females from metabolic disorders in a physiological dose-range, exposure at a wrong period of time or at inappropriate levels can elicit adverse metabolic consequences like exposure to androgenic chemicals. In males, characterized by a high ratio of androgens to estrogens, the presence of a potent androgen antagonist or a combination of increased estrogeno-mimetic and decreased androgeno-mimetic activities will create an overall estrogenic effect.

Estrogens and androgens signal via nuclear acting receptors, $\mathrm{ER} \alpha / \beta$ and $\mathrm{AR}$, respectively. Estrogens signal as well via the G protein-coupled estrogen receptor (GPER). Genetic mouse models deficient for aromatase or for ER $\alpha$ have demonstrated that estrogens regulate insulin signaling and glucose homeostasis as well as body weight composition, fat distribution and inflammation, in both males and females (Table 1). GPER also regulates metabolic parameters associated with obesity and diabetes although distinct effects related to the timing of appearance of metabolic disturbances, body composition and inflammatory status depend on the sex (Table 1). In contrast the role of ER $\beta$ is less clear as no obesity is observed in males while in females, enhanced body weight and fat mass is described together with improved insulin sensitivity and glucose tolerance (Table 1) probably as a result of enhanced signaling of the insulin sensitizer PPAR $\gamma$ [21]. Sex-specific effects of estrogens may result from the expression levels of ERs and AR differently expressed in the various metabolic tissues and depending on sex. Interaction/compensation mechanisms have also been described in the muscle and adipose tissue in which ER $\alpha$ and ER $\beta$ exert opposite actions [22] and the integrated response is obviously distinct in males and females because of the pivotal role of the androgens in metabolic regulations in males. For example, male AR-deficient mice show late onset of obesity with large subcutaneous fat expansion typical of females (Table 1). In addition, regulation of body composition is also controlled by multiple other hormones including the glucocorticoids, the thyroid hormones and the growth hormone with both excess and deficiency leading to metabolic abnormalities.

\section{Environmental exposure to endocrine disruptors and sex dimorphic effects on metabolism}


Many outcomes characterizing the metabolic state of an individual are sexually marked and several chemicals including BPA, PCBs, dioxins and phthalates, because of their endocrine-disrupting activities, may be expected to induce sex-specific metabolic disturbances (i.e., present in one sex but not the other or stronger in one sex). However few studies have simultaneously investigated both sexes to date. For example, it was independently reported that TBT exposure of adult male mice targeted the pancreas resulting in disruption of glucose homeostasis [23] while exposed female rats showed a profile of insulin resistance with enhanced body weight and central adiposity [24] suggesting that the primary target is the adipocytes in females and the pancreas in males. Using male and female siblings, it was also shown that early life exposure to TCDD and to a lesser extent to PCB153 and BPA could program for an altered metabolic phenotype in adulthood and that sexdependent factors contributed to the final phenotypic outcome [25,26]. However, within these studies a diversity of outcomes was found and the most evident sex-specific effect was observed with TCDD shown to enhance fat pads in females and to decrease them in males $[25,26]$. More recently, BPA was found to program estrogen signaling in the adult liver of mice exposed in utero in line with the $\mathrm{DOHaD}$ hypothesis. It resulted in abnormal hepatic gene expression of estrogen-responsive genes including enhancement of ERs in females and their decrease in males [27]. Importantly, enhancing hepatic ER $\alpha$ signaling lessened the impact of obesity on diabetes and cardiovascular risk in males [28] emphasizing the deleterious impact of BPA [3-8].

A major difficulty with endocrine disruptors resides in the uncertainties resulting from the integrative impact of the combined exposure to a plethora of endocrine disruptors which de facto constitutes the real exposure. Indeed, evaluations based on the additivity of the effects of each individual chemical underestimate the risk. This is known as "the something from nothing" or "cocktail effect" based on experiments in which chemicals were added in the mixture at doses too low to produce an adverse effect when studied alone, yet the mixture exerted adverse effects [29]. It is then more relevant to challenge mice with mixtures containing low-dose endocrine disruptors with different hormono-mimetic properties in an attempt to mimic real-world exposure and to identify sex-different metabolic sensitivities for a better protection of individuals.

In the laboratory, we approached the question of multi-exposure through setting an original model of mice chronically exposed to chemicals (categorized with either estrogenoor anti-androgen activities) at doses in the range of the tolerable daily intake (TDI) for each 
chemical (i.e., TCDD, PCB153, BPA and the diethylhexyl-phthalate, DEHP), thus not expected to produce any effect when added individually. In addition, mice were fed a high-fat diet to clarify the question of the additional metabolic risk induced by the mixture of pollutants and both threats were applied lifelong starting 5 weeks before mating of the dams. Interestingly, the female offspring exposed to the mixture developed at adulthood an impairment of glucose tolerance and hepatic estrogen signaling which may be linked to concurrent reduction of hepatic ER $\alpha$ expression and enhancement of the expression of the estrogen sulfotransferase that inactivates estrogens. This suggested that pollutants lowered the protection exerted by estrogen against the development of metabolic disorders. Importantly, these features observed in the absence of any weight gain were not described in males [30]. Males had impaired cholesterol metabolism suggesting that the mixture could have impacted the estrogen/androgen balance as androgens regulate lipid accumulation and cholesterol metabolism in the male liver [31,32] and estrogens protect females from cardiovascular diseases [2]. Conversely, immature females with low levels of circulating estrogens showed alleviation of metabolic outcomes together with enhanced glucose tolerance, enhanced lean mass and muscle insulin sensitivity and reduced inflammation in the adipose tissue [33], all consistent with enhanced and benefitial estrogen signaling as shown in Table 1. The agematched sibling males did not show any change in body composition or in glucose intolerance [33], again pointing to the sex-specificity of the outcomes resulting from an exposure to a mixture of pollutants with evidences of estrogeno-mimetic activities. Interestingly, mice exposure to pollutants in a standard diet did not reproduce the effects observed with combined challenges regarding estrogen signaling in females and cholesterol metabolism in males fed a high-fat diet. Again, effects were distinct between males and females. Indeed, females but not males showed dyslipidemia and profound changes in the expression of hepatic genes related to cholesterol metabolism while males were hyperglycemic but not obese [34]. These data highlight the complexity of evaluating the metabolic consequences of an exposure to multiple chemicals because of the interference with other parameters such as diet. Again, this reflects the reality of human exposure because the chemicals to which humans are exposed depend on food habits, geographical localization and of the sex of the individual.

\section{Conclusions and future directions}


Recent decades have seen the emergence of the concept of endocrine disruption and the identification of a thousand of chemicals having a mode of action coherent with the definition of an endocrine disruptor based on the interference with any hormone action. Today it is well recognized that while obesity and metabolic disorders are multifactorial diseases, the endocrine disruptors are one of the multiple etiologic factors. However, until recently only males have been studied and there is a lack of information regarding the metabolic impact of endocrine disruptors in females. The National Institutes of Health (NIH) has recently mandated to consider sex as a biological variable in preclinical research [35]. Hopefully, this will give an impulse for a better understanding of the sex-biased mechanisms linked to endocrine disruption by chemicals that could be helpful to improve and personalize treatments of diseases for which obesity is a risk factor such as the metabolic syndrome and the hormono-dependent cancers. 
1. WHO: World health organization, obesity and overweight, fact sheet $\mathbf{3 1 1}$. http://wwwwhoint/mediacentre/factsheets/fs311/en/ (2014).

2. Mauvais-Jarvis F: Sex differences in metabolic homeostasis, diabetes, and obesity. Biology of sex differences (2015) 6(14.

3. Barouki R, Gluckman PD, Grandjean P, Hanson M, Heindel JJ: Developmental origins of noncommunicable disease: Implications for research and public health. Environ Health (2012) $11(42$.

4. Heindel JJ, Blumberg B, Cave M, Machtinger R, Mantovani A, Mendez MA, Nadal A, Palanza P, Panzica G, Sargis R, Vandenberg LN et al: Metabolism disrupting chemicals and metabolic disorders. Reprod Toxicol (2017) 68(3-33.

5. Nadal A, Quesada I, Tuduri E, Nogueiras R, Alonso-Magdalena P: Endocrine-disrupting chemicals and the regulation of energy balance. Nature reviews Endocrinology (2017).

6. Le Magueresse-Battistoni B, Labaronne E, Vidal H, Naville D: Endocrine disrupting chemicals in mixture and obesity, diabetes and related metabolic disorders. World J Biol Chem (2017) 8(2):108-119.

7. Marmugi A, Ducheix S, Lasserre F, Polizzi A, Paris A, Priymenko N, Bertrand-Michel J, Pineau T, Guillou H, Martin PG, Mselli-Lakhal L: Low doses of bisphenol a induce gene expression related to lipid synthesis and trigger triglyceride accumulation in adult mouse liver. Hepatology (Baltimore, Md (2012) 55(2):395-407.

8. Gore AC, Chappell VA, Fenton SE, Flaws JA, Nadal A, Prins GS, Toppari J, Zoeller RT: Edc-2: The endocrine society's second scientific statement on endocrine-disrupting chemicals. Endocrine reviews (2015) 36(6):E1-E150.

9. Casals-Casas C, Desvergne B: Endocrine disruptors: From endocrine to metabolic disruption. Annual review of physiology (2011) 73(135-162.

10. Haugen AC, Schug TT, Collman G, Heindel JJ: Evolution of dohad: The impact of environmental health sciences. Journal of developmental origins of health and disease (2015) 6(2):55-64.

11. Chamorro-Garcia R, Blumberg B: Transgenerational effects of obesogens and the obesity epidemic. Current opinion in pharmacology (2014) 19(153-158.

12. WHO: Global assessment of the state of the science of endocrine disruptors, . WHOIPCS/UNEP/ILO-2002 (2002) Available from: URL: http://www.who.int/ipcs/publications/new issues/endocrine disruptors/en// 
13. Newbold RR, Padilla-Banks E, Jefferson WN: Environmental estrogens and obesity. Molecular and cellular endocrinology (2009) 304(1-2):84-89.

14. Grun F, Blumberg B: Minireview: The case for obesogens. Molecular endocrinology (Baltimore, Md (2009) 23(8):1127-1134.

15. Janesick AS, Blumberg B: Obesogens: An emerging threat to public health. American journal of obstetrics and gynecology (2016) 214(5):559-565.

16. Nohara K, Liu S, Meyers MS, Waget A, Ferron M, Karsenty G, Burcelin R, Mauvais-Jarvis F: Developmental androgen excess disrupts reproduction and energy homeostasis in adult male mice. The Journal of endocrinology (2013) 219(3):259-268.

17. Dang ZC, Lowik C: Dose-dependent effects of phytoestrogens on bone. Trends in endocrinology and metabolism: TEM (2005) 16(5):207-213.

18. Mauvais-Jarvis F, Clegg DJ, Hevener AL: The role of estrogens in control of energy balance and glucose homeostasis. Endocrine reviews (2013) 34(3):309-338.

19. Fagman JB, Wilhelmson AS, Motta BM, Pirazzi C, Alexanderson C, De Gendt K, Verhoeven G, Holmang $A$, Anesten $F$, Jansson JO, Levin $M$ et al: The androgen receptor confers protection against diet-induced atherosclerosis, obesity, and dyslipidemia in female mice. FASEB journal : official publication of the Federation of American Societies for Experimental Biology (2015) 29(4):1540-1550.

20. Navarro G, Allard C, Xu W, Mauvais-Jarvis F: The role of androgens in metabolism, obesity, and diabetes in males and females. Obesity (Silver Spring, Md (2015) 23(4):713-719.

21. Foryst-Ludwig A, Clemenz M, Hohmann S, Hartge M, Sprang C, Frost N, Krikov M, Bhanot S, Barros R, Morani A, Gustafsson JA et al: Metabolic actions of estrogen receptor beta (erbeta) are mediated by a negative cross-talk with ppargamma. PLoS genetics (2008) 4(6):e1000108.

22. Barros RP, Machado UF, Gustafsson JA: Estrogen receptors: New players in diabetes mellitus. Trends in molecular medicine (2006) 12(9):425-431.

23. Zuo Z, Wu T, Lin M, Zhang S, Yan F, Yang Z, Wang Y, Wang C: Chronic exposure to tributyltin chloride induces pancreatic islet cell apoptosis and disrupts glucose homeostasis in male mice. Environmental science \& technology (2014) 48(9):5179-5186.

24. Bertuloso BD, Podratz PL, Merlo E, de Araujo JF, Lima LC, de Miguel EC, de Souza LN, Gava AL, de Oliveira M, Miranda-Alves L, Carneiro MT et al: Tributyltin chloride leads to adiposity and impairs metabolic functions in the rat liver and pancreas. Toxicology letters (2015) 235(1):45-59. 
25. van Esterik JC, Dolle ME, Lamoree MH, van Leeuwen SP, Hamers T, Legler J, van der Ven LT: Programming of metabolic effects in $\mathrm{c} 57 \mathrm{bl} / 6 \mathrm{jxfvb}$ mice by exposure to bisphenol a during gestation and lactation. Toxicology (2014) 321(40-52.

26. van Esterik JC, Verharen HW, Hodemaekers HM, Gremmer ER, Nagarajah B, Kamstra JH, Dolle $M E$, Legler J, van der Ven LT: Compound- and sex-specific effects on programming of energy and immune homeostasis in adult c57bl/6jxfvb mice after perinatal tcdd and pcb 153. Toxicology and applied pharmacology (2015) 289(2):262-275.

27. Ilagan Y, Mamillapalli R, Goetz LG, Kayani J, Taylor HS: Bisphenol-a exposure in utero programs a sexually dimorphic estrogenic state of hepatic metabolic gene expression. Reprod Toxicol (2017) 71(84-94.

28. Zhu L, Martinez MN, Emfinger CH, Palmisano BT, Stafford JM: Estrogen signaling prevents diet-induced hepatic insulin resistance in male mice with obesity. American journal of physiology Endocrinology and metabolism (2014) 306(10):E1188-1197.

29. Kortenkamp A: Low dose mixture effects of endocrine disrupters and their implications for regulatory thresholds in chemical risk assessment. Current opinion in pharmacology (2014) 19(105-111.

30. Naville D, Pinteur C, Vega N, Menade $\mathrm{Y}$, Vigier M, Le Bourdais A, Labaronne E, Debard C, Luquain-Costaz $\mathrm{C}$, Begeot $\mathrm{M}$, Vidal $\mathrm{H}$ et al: Low-dose food contaminants trigger sex-specific, hepatic metabolic changes in the progeny of obese mice. FASEB journal : official publication of the Federation of American Societies for Experimental Biology (2013) 27(9):3860-3870.

31. Zhang H, Liu Y, Wang L, Li Z, Wu J, Rahman N, Guo Y, Li D, Li N, Huhtaniemi I, Tsang SY et al: Differential effects of estrogen/androgen on the prevention of nonalcoholic fatty liver disease in the male rat. Journal of lipid research (2013) 54(2):345-357.

32. Lin HY, Yu IC, Wang RS, Chen YT, Liu NC, Altuwaijri S, Hsu CL, Ma WL, Jokinen J, Sparks JD, Yeh $S$ et al: Increased hepatic steatosis and insulin resistance in mice lacking hepatic androgen receptor. Hepatology (Baltimore, Md (2008) 47(6):1924-1935.

33. Naville D, Labaronne E, Vega N, Pinteur C, Canet-Soulas E, Vidal H, Le Magueresse-Battistoni B: Metabolic outcome of female mice exposed to a mixture of low-dose pollutants in a diet-induced obesity model. PloS one (2015) 10(4):e0124015.

34. Labaronne E, Pinteur C, Vega N, Pesenti S, Julien B, Meugnier-Fouilloux E, Vidal H, Naville D, Le Magueresse-Battistoni $B$ : Low-dose pollutant mixture triggers metabolic disturbances in female mice leading to common and specific features as compared to a high-fat diet. The Journal of nutritional biochemistry (2017) 45(83-93. 
35. Mauvais-Jarvis F, Arnold AP, Reue K: A guide for the design of pre-clinical studies on sex differences in metabolism. Cell metabolism (2017) 25(6):1216-1230.

36. Heine PA, Taylor JA, Iwamoto GA, Lubahn DB, Cooke PS: Increased adipose tissue in male and female estrogen receptor-alpha knockout mice. Proceedings of the National Academy of Sciences of the United States of America (2000) 97(23):12729-12734.

37. Ohlsson C, Hellberg N, Parini P, Vidal O, Bohlooly YM, Rudling M, Lindberg MK, Warner M, Angelin B, Gustafsson JA: Obesity and disturbed lipoprotein profile in estrogen receptoralpha-deficient male mice. Biochemical and biophysical research communications (2000) 278(3):640-645.

38. Ribas V, Nguyen MT, Henstridge DC, Nguyen AK, Beaven SW, Watt MJ, Hevener AL: Impaired oxidative metabolism and inflammation are associated with insulin resistance in eralphadeficient mice. American journal of physiology Endocrinology and metabolism (2010) 298(2):E304-319.

39. Zhu L, Brown WC, Cai Q, Krust A, Chambon P, McGuinness OP, Stafford JM: Estrogen treatment after ovariectomy protects against fatty liver and may improve pathwayselective insulin resistance. Diabetes (2013) 62(2):424-434.

40. Davis KE, M DN, Sun K, W MS, J DB, J AZ, Zeve D, L DH, D WC, L MG, Xu Y et al: The sexually dimorphic role of adipose and adipocyte estrogen receptors in modulating adipose tissue expansion, inflammation, and fibrosis. Molecular metabolism (2013) 2(3):227-242.

41. Martensson UE, Salehi SA, Windahl S, Gomez MF, Sward K, Daszkiewicz-Nilsson J, Wendt A, Andersson N, Hellstrand P, Grande PO, Owman C et al: Deletion of the g protein-coupled receptor 30 impairs glucose tolerance, reduces bone growth, increases blood pressure, and eliminates estradiol-stimulated insulin release in female mice. Endocrinology (2009) 150(2):687-698.

42. Sharma G, Hu C, Brigman JL, Zhu G, Hathaway HJ, Prossnitz ER: Gper deficiency in male mice results in insulin resistance, dyslipidemia, and a proinflammatory state. Endocrinology (2013) 154(11):4136-4145.

43. Sato $T$, Matsumoto $T$, Yamada $T$, Watanabe $T$, Kawano $H$, Kato $S$ : Late onset of obesity in male androgen receptor-deficient (ar ko) mice. Biochemical and biophysical research communications (2003) 300(1):167-171.

44. Fan W, Yanase T, Nomura M, Okabe T, Goto K, Sato T, Kawano H, Kato S, Nawata H: Androgen receptor null male mice develop late-onset obesity caused by decreased energy expenditure and lipolytic activity but show normal insulin sensitivity with high adiponectin secretion. Diabetes (2005) 54(4):1000-1008. 
45. Yu IC, Lin HY, Liu NC, Wang RS, Sparks JD, Yeh S, Chang C: Hyperleptinemia without obesity in male mice lacking androgen receptor in adipose tissue. Endocrinology (2008) 149(5):2361-2368.

46. Navarro G, Xu W, Jacobson DA, Wicksteed B, Allard C, Zhang G, De Gendt K, Kim SH, Wu H, Zhang $H$, Verhoeven $G$ et al: Extranuclear actions of the androgen receptor enhance glucose-stimulated insulin secretion in the male. Cell metabolism (2016) 23(5):837-851.

47. Van Sinderen ML, Steinberg GR, Jorgensen SB, To SQ, Knower KC, Clyne CD, Honeyman J, Chow JD, Herridge KA, Jones ME, Simpson ER et al: Hepatic glucose intolerance precedes hepatic steatosis in the male aromatase knockout (arko) mouse. PloS one (2014) 9(2):e87230.

48. Van Sinderen M, Steinberg G, Jorgensen SB, Honeyman J, Chow JDY, Simpson ER, Jones MEE, Boon WC: Sexual dimorphism in the glucose homeostasis phenotype of the aromatase knockout (arko) mice. The Journal of steroid biochemistry and molecular biology (2017) 170(39-48.

Annotated references ( $\bullet$ of special interest; $\bullet \bullet$ of outstanding interest)

- Ref 2: This review reports the most fundamental sex differences in metabolic homeostasis

- - Ref 8: This review covers most adverse effects induced by endocrine disruptors and point to the necessity at considering endocrine principles to better translate findings to human health and give tools to policymakers to improve risk assessment

- Ref 11: The authors of the review describe their original studies demonstrating that chemicals may exhibit obesogenic properties and that exposure to obesogen chemicals resulted in the transmission of obesity related phenotypes through at least three generations

- - Ref 29: The author comments on the pioneering experiments made in his laboratory and demonstrating the "something from nothing phenomenon" with mixtures of endocrine disruptors. He points to the necessity at elucidating the risk posed by mixtures of endocrine disruptors across the life span

- - Ref 30: This study originally demonstrated that a mixture of low-dosed endocrine disruptors triggered sex-specific metabolic disturbances in a model of mice lifelong exposed to the chemicals 


\begin{tabular}{|c|c|c|c|c|c|}
\hline \multirow{2}{*}{ Name } & \multirow[b]{2}{*}{ Gene } & \multirow[b]{2}{*}{ Knockout } & \multicolumn{2}{|c|}{ Metabolic phenotype compared to wild-type mice } & \multirow[b]{2}{*}{ References } \\
\hline & & & Females & Males & \\
\hline \multirow[b]{2}{*}{$\mathrm{ER} \alpha$} & \multirow[b]{2}{*}{ Nr3a1 } & \multirow[b]{2}{*}{$\begin{array}{c}\text { Global } \\
(\alpha \text { ERKO })\end{array}$} & \multicolumn{2}{|c|}{$\begin{array}{l}\text { Obesity and increase in white adipose tissue (WAT); insulin } \\
\text { resistance and impaired glucose tolerance }\end{array}$} & \multirow{2}{*}{$\begin{array}{c}{[36]} \\
{[37,38]}\end{array}$} \\
\hline & & & $\begin{array}{l}\text { Elevated fasting insulin, leptin, } \\
\text { triglyceride (TG), cholesterol } \\
\text { levels. No difference in Free } \\
\text { Fatty Acid (FFA) levels }\end{array}$ & $\begin{array}{l}\text { Enhanced serum leptin levels } \\
\text { after sexual maturation. } \\
\text { Increased serum cholesterol } \\
\text { but no difference in insulin, } \\
\text { FFA and TG levels }\end{array}$ & \\
\hline $\mathrm{ER} \alpha$ & Nr3a1 & $\begin{array}{l}\text { Liver specific } \\
\quad(\text { LKO) }\end{array}$ & 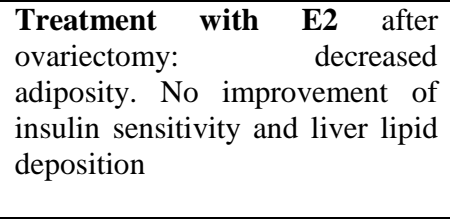 & $\begin{array}{l}\text { Under High-fat diet (HFD): } \\
\text { decreased liver and whole } \\
\text { body insulin sensitivity; } \\
\text { impaired liver insulin } \\
\text { signaling and increased liver } \\
\text { TG. }\end{array}$ & {$[28,39]$} \\
\hline $\mathrm{ER} \alpha$ & Nr3a1 & $\begin{array}{l}\text { Adipocyte } \\
\text { specific } \\
(\text { AdipoER } \alpha)\end{array}$ & $\begin{array}{l}\text { Increased weight gain from } 12 \\
\text { weeks of age and increased fat } \\
\text { mass. No change in glucose } \\
\text { tolerance. No modification of } \\
\text { inflammatory markers }\end{array}$ & $\begin{array}{l}\text { No difference in body weight } \\
\text { or adiposity through 25+ } \\
\text { weeks of age. Strong glucose } \\
\text { intolerance. } \\
\text { inflammation }\end{array}$ & {$[40]$} \\
\hline $\mathrm{ER} \beta$ & $\mathrm{Nr} 3 \mathrm{a} 2$ & $\begin{array}{c}\text { Global } \\
(\beta \text { ERKO) }\end{array}$ & $\begin{array}{l}\text { Under HFD: } \\
\text { Increased body weight and fat } \\
\text { mass. Decreased TG content in } \\
\text { liver and muscle. Improvement } \\
\text { of hepatic and muscular insulin } \\
\text { signaling. Improved systemic } \\
\text { insulin sensitivity and glucose } \\
\text { tolerance }\end{array}$ & $\begin{array}{l}\text { No development of obesity } \\
\text { after sexual maturation }\end{array}$ & {$[21,37]$} \\
\hline \multirow[t]{2}{*}{$\begin{array}{l}\text { GPR30/ } \\
\text { GPER1 }\end{array}$} & \multirow[t]{2}{*}{ Gper1 } & \multirow[t]{2}{*}{ Global } & $\begin{array}{l}\text { At age } 6 \text { months: } \\
\text { Hyperglycemia and impaired } \\
\text { glucose tolerance. Decreased } \\
\text { insulin release by pancreatic } \\
\text { islets. Reduced body growth. No } \\
\text { change in body fat }\end{array}$ & $\begin{array}{l}\text { At age } 6 \text { months: No change } \\
\text { in blood glucose and plasma } \\
\text { insulin levels; normal glucose } \\
\text { tolerance. No difference in } \\
\text { body weight and fat }\end{array}$ & [41] \\
\hline & & & & $\begin{array}{l}\text { At age } 12 \text { months: Increased } \\
\text { body weight and adipose } \\
\text { tissue. Altered lipid } \\
\text { metabolism } \\
\end{array}$ & {$[42]$} \\
\hline $\mathrm{AR}$ & $\mathrm{Nr} 3 \mathrm{c} 4$ & Global & No obesity & $\begin{array}{l}\text { Late onset obesity (30-week } \\
\text { old) with increased white } \\
\text { adipose tissues }\end{array}$ & {$[43,44]$} \\
\hline \multirow[b]{2}{*}{ AR } & \multirow[b]{2}{*}{$\mathrm{Nr} 3 \mathrm{c} 4$} & \multirow[b]{2}{*}{$\begin{array}{c}\text { Liver specific } \\
\text { (H-AR-/y and } \\
\text { H-AR-/-) }\end{array}$} & \multicolumn{2}{|c|}{$\begin{array}{l}\text { Under normal diet: Growth not affected for } 24 \text { weeks; no } \\
\text { difference in fasting blood glucose and serum insulin levels }\end{array}$} & {$[32]$} \\
\hline & & & $\begin{array}{l}\text { Under HFD: } \begin{array}{l}\text { Resistant } \\
\text { obesity; little liver steatosis }\end{array} \\
\text { ste }\end{array}$ & $\begin{array}{l}\text { Under HFD: Increased body } \\
\text { weight ( } 8 \text { weeks of diet) and } \\
\text { adiposity. Increased liver } \\
\text { steatosis. Enhanced fasting } \\
\text { blood glucose and serum } \\
\text { insulin levels }\end{array}$ & {$[32]$} \\
\hline AR & $\mathrm{Nr} 3 \mathrm{c} 4$ & $\begin{array}{l}\text { Adipose tissue } \\
\text { specific (A- } \\
\text { AR-/y) }\end{array}$ & No data & $\begin{array}{l}\text { No alteration in body weight } \\
\text { and adiposity (20-week old) }\end{array}$ & {$[45]$} \\
\hline AR & $\mathrm{Nr} 3 \mathrm{c} 4$ & $\begin{array}{l}\text { Pancreatic } \beta \\
\text { cells specific } \\
(\beta \mathrm{ARKO})\end{array}$ & $\begin{array}{l}\text { Under normal diet: normal } \\
\text { glucose tolerance }\end{array}$ & $\begin{array}{l}\text { Under normal diet: glucose } \\
\text { intolerance (12-weeks old) } \\
\text { Under } 9 \text { weeks of HFD: } \\
\text { Hyperglycemia and glucose } \\
\text { intolerance }\end{array}$ & [46] \\
\hline aromatase & Cyp19a1 & Global & $\begin{array}{l}\text { At } 3 \text { months of age: Increased } \\
\text { body weight and omental WAT } \\
\text { weights. Glucose intolerance, no } \\
\text { change in global insulin } \\
\text { sensitivity or pyruvate tolerance. }\end{array}$ & $\begin{array}{l}\text { At } 3 \text { months of age: No } \\
\text { change in body weight. } \\
\text { Decreased glucose and } \\
\text { pyruvate tolerance, no change } \\
\text { in insulin sensitivity. High } \\
\text { blood glucose and plasma } \\
\text { insulin levels. }\end{array}$ & {$[47,48]$} \\
\hline
\end{tabular}

Table 1: Metabolic phenotypes of steroid receptor- or aromatase-deficient mice 